Review

\title{
Staphylococcus aureus $\alpha$-Toxin: Nearly a Century of Intrigue
}

\section{Bryan J. Berube ${ }^{1}$ and Juliane Bubeck Wardenburg ${ }^{1,2, *}$}

1 Department of Microbiology, The University of Chicago, 920 E. 58th Street Chicago, IL 60637, USA; E-Mail: bberube@bsd.uchicago.edu

2 Department of Pediatrics, The University of Chicago, 5721 S. Maryland Ave. Chicago, IL 60637, USA

* Author to whom correspondence should be addressed; E-Mail: jbubeckw@peds.bsd.uchicago.edu; Tel.: +1-773-834-9763; Fax: +1-773-834-8150.

Received: 27 April 2013; in revised form: 28 May 2013 / Accepted: 3 June 2013 /

Published: 13 June 2013

\begin{abstract}
Staphylococcus aureus secretes a number of host-injurious toxins, among the most prominent of which is the small $\beta$-barrel pore-forming toxin $\alpha$-hemolysin. Initially named based on its properties as a red blood cell lytic toxin, early studies suggested a far greater complexity of $\alpha$-hemolysin action as nucleated cells also exhibited distinct responses to intoxication. The hemolysin, most aptly referred to as $\alpha$-toxin based on its broad range of cellular specificity, has long been recognized as an important cause of injury in the context of both skin necrosis and lethal infection. The recent identification of ADAM10 as a cellular receptor for $\alpha$-toxin has provided keen insight on the biology of toxin action during disease pathogenesis, demonstrating the molecular mechanisms by which the toxin causes tissue barrier disruption at host interfaces lined by epithelial or endothelial cells. This review highlights both the historical studies that laid the groundwork for nearly a century of research on $\alpha$-toxin and key findings on the structural and functional biology of the toxin, in addition to discussing emerging observations that have significantly expanded our understanding of this toxin in $S$. aureus disease. The identification of ADAM10 as a proteinaceous receptor for the toxin not only provides a greater appreciation of truths uncovered by many historic studies, but now affords the opportunity to more extensively probe and understand the role of $\alpha$-toxin in modulation of the complex interaction of $S$. aureus with its human host.
\end{abstract}

Keywords: $\alpha$-toxin; Staphylococcus aureus; pore-forming toxins; ADAM10; cellular responses; $S$. aureus vaccine and therapeutic 


\section{Introduction}

Staphylococcus aureus $\alpha$-hemolysin ( $\alpha$-toxin, Hla) is the prototype for the class of small $\beta$-barrel pore-forming cytotoxins (PFTs) [1-4]. S. aureus $\alpha$-toxin is secreted as a water soluble monomer, capable of binding and oligomerization into a heptameric structure on the host cell membrane $[5,6]$. This molecular transformation on susceptible host cells culminates in the extension of a membrane-perforating 1-3 nm $\beta$-hairpin lined amphipathic pore through the eukaryotic lipid bilayer, allowing for the flow of $\mathrm{Ca}^{2+}$ and $\mathrm{K}^{+}$, ATP, and low molecular weight molecules with a cutoff between 1 and $4 \mathrm{kDa}$ through the barrel of the pore [1]. While pore formation and cellular lysis are a prominent consequence of $\alpha$-toxin action, a number of studies in recent years have defined cellular responses to sublytic intoxication, notably the alteration of cell signaling pathways that govern cell proliferation, inflammatory responses, cytokine secretion, and cell-cell interactions (extensively reviewed in [1,7]; see also [8-13]).

For many years the relevance of $\alpha$-toxin-mediated injury to human disease was the subject of debate as multiple investigations focused on the exquisite susceptibility of rabbit erythrocytes to lysis, in contrast to a relative insensitivity of human red cells [14-18]. However, in 1964, Siegel and Cohen demonstrated that $\alpha$-toxin causes the aggregation of human platelets at sublytic concentrations [19]. Since then, $\alpha$-toxin has been shown to intoxicate a wide range of human cell types, including epithelial cells, endothelial cells, and an array of other hematopoietic-lineage cells including T cells, monocytes, macrophages, and neutrophils [1,7,13,18,20-24]. Further, multiple studies have investigated the human and small animal host response to the toxin, both shedding light on how this toxin causes injury and defining salient features of the cellular and organismal response to the toxin [9,11,13,20,25-33].

$S$. aureus $\alpha$-toxin has been the subject of a number of exceptional reviews that provide a detailed record of the many studies that have contributed to our current knowledge of the toxin; we recommend these to the reader [1,7,34-36]. In this review, we will highlight key observations on $\alpha$-toxin that illustrate the defining features of toxin biology and its role in disease pathogenesis. Given the common use of pore-forming toxins by bacterial pathogens, it is anticipated that the ever-increasing knowledge of $S$. aureus $\alpha$-toxin will likely provide greater insight on the biologic function of this family of toxins. While many early investigations on $\alpha$-toxin lack the sophisticated experimental techniques currently available, these observations can now be viewed in light of our existing knowledge to have provided extraordinary fundamental insights on $S$. aureus disease and $\alpha$-toxin-mediated injury. These seminal discoveries have been validated over decades of research, now expanded in scope through newer observations that provide molecular detail of toxin action and more clearly define the contribution of $\alpha$-toxin to $S$. aureus disease pathogenesis. Our wealth of insight on this toxin highlights interesting new areas for investigation and defines the potential to target $\alpha$-toxin through preventive and therapeutic strategies to combat human $S$. aureus disease, both of which will be explored in this review.

\section{Historic Studies}

Investigation on the toxic activity of staphylococcal supernatants began in the late $1800 \mathrm{~s}$. These initial studies attributed lethality in guinea pigs and rabbits, dermonecrosis, inflammation of the conjuctival epithelium, and hemolysis to toxigenic substances secreted by $S$. aureus [37-43]. However, 
the precipitating event that sparked a rigorous examination of $S$. aureus and its toxins came in the late 1920s following a tragedy in Bundaberg, Australia [14,35,44]. Twenty-one children in that town were immunized with a diphtheria toxin-antitoxin preparation. Within hours, 16 children experienced vomiting, high fever, unconsciousness, and convulsions. Within two days, 12 of the children had died, while all of the surviving children developed abscesses at the site of the immunization. F. McFarlane Burnet, then in the early days of his career, was commissioned by the Commonwealth of Australia to further investigate the cause of this tragedy. The Royal Commission noted in their investigation that, "massive production of toxic substances must have taken place if staphylococci were the responsible agents" [44]. Burnet discovered that culture supernatants from the vaccine-contaminating S. aureus strain caused hemolysis and lethal injury upon injection into rabbits [14,15,44,45]. Further, he provided a cohesive analysis of other $S$. aureus isolates that had been investigated at that time for their toxic properties, concluding that a single, heat-labile antigenic substance secreted by this pathogen was responsible for multiple biologic effects including hemolysis in vitro, dermonecrosis upon intradermal inoculation in vivo, and acute death upon injection into a rabbit. Burnet and his contemporaries also made the key observation that active immunization with formalin-treated supernatant preparations or passive immunization with antitoxin containing serum derived from immune rabbits afforded protection against disease in naïve rabbits and neutralized hemolytic and necrotic activity [14,15].

In the years immediately following Burnet's studies, Glenny and Stevens described two immunologically distinct toxins secreted by $S$. aureus that displayed species-specific hemolytic activity. They designated the rabbit-specific toxin as $\alpha$-toxin [46]. Over the next few decades, crude preparations of $\alpha$-toxin from staphylococcal supernatants led to several significant observations. In particular, rabbit erythrocytes were shown to be exquisitely sensitive to hemolysis by $\alpha$-toxin [47-49]. This sensitivity was paralleled by comparative toxicity studies in a number of small animals, which demonstrated that rabbits succumb to the lethal effects of the toxin at an $\mathrm{LD}_{50}$ of $2 \mu \mathrm{g} / \mathrm{kg}$ body weight, the lowest of any species tested [34].

In the 1960s, isolation of purified ãtoxin from culture supernatants allowed for a wide range of structural, biochemical, and cellular biological experiments to be performed [50,51], tremendously advancing knowledge of this toxin and more broadly, the pore-forming family of toxins. Early experiments with purified $\alpha$-toxin indicated the toxin might function by disrupting host cell membranes, initially noted by Bernheimer and Schwartz who stated, "In view of the rapidity with which it brings about cell damage and in view of its remarkable lytic action on red blood cells, as distinct from diphtheria, tetanus, and botulinum toxin which have neither of these properties, perhaps the best hypothesis is that it alters or disrupts cell membranes" [51]. Consistent with this hypothesis, low molecular weight markers of $<1-2 \mathrm{~nm}$ in size leaked out of toxin-treated cells [52-55], oligomeric structures could be isolated from red cell membrane preparations [56], and membrane lesions could be visualized in the plasma membrane of toxin-treated cells [57]. While these effects were not specific to rabbit erythrocytes, the molecular mechanism by which $\alpha$-toxin exhibited selective cytotoxicity across a wide array of cells remained a focus of investigation for many years. 


\section{Properties of $\alpha$-Toxin}

\subsection{Toxin Structure and Regulation of Production}

The gene coding for $\alpha$-toxin was discovered in the early 1980 s utilizing a recombinant phage-based strategy that transferred the ability to lyse red blood cells to E. coli [58]. Further studies narrowed the region responsible for toxin activity to a 1620 base pair genomic DNA fragment [59]; the full DNA coding and protein sequence being identified shortly after in 1984 [60]. Present in a single copy on the staphylococcal chromosome, the hla locus is rather invariant across sequenced $S$. aureus strains, with almost complete conservation of primary amino acid sequence. The hla locus encodes a 319 amino acid protein containing a 26 amino acid leader peptide predicted to be $\alpha$-helical in structure [60]. The polypeptide is processed to yield a mature extracellular protein of 293 amino acids weighing approximately $33 \mathrm{kDa}$ [61]. Circular dichroism studies revealed the mature toxin is composed almost entirely of $\beta$-strands with little to no $\alpha$-helical structure [62].

Early evidence suggested that $\alpha$-toxin monomers aggregated into an oligomeric structure on the host cell surface. Electron micrographic images of Hla-treated cells or artificial liposomes led to the discovery of ring-like structures $10 \mathrm{~nm}$ in diameter with 6-7 subunits and a central pore of approximately 2-3 nm [56,57,63-67]. Initial biochemical studies, including purification of membrane-bound oligomers, led to the determination that $\alpha$-toxin formed stable hexamers [56,68-70]. Gouaux and colleagues clarified these observations, employing X-ray diffraction analysis to propose a heptameric toxin structure [6]. This heptameric structure was confirmed in 1996 when Song and colleagues solved the crystal structure of the fully assembled toxin pore (Figure 1, [5]). The holotoxin is described to encompass three broad domains: (1) the cap domain on the extracellular face of the toxin, exposed to the aqueous environment, defining the entry of the pore; (2) the rim domain that is juxtaposed to the outer leaflet of the host plasma membrane; and (3) the stem domain that forms the membrane-perforating $\beta$-barrel pore [5].

Figure 1. Structure of $\alpha$-toxin. Crystal structure of $\alpha$-toxin derived from the RCSB Protein Data Bank (PDB, 7AHL) and prepared using PYMOL, noting the regions of the toxin that demarcate the entry of the pore (Cap), the membrane-interfacing region (Rim), and the membrane perforating stem.

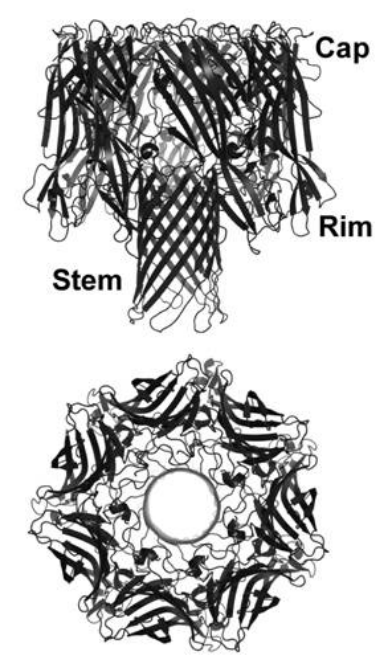


Expression of the $\alpha$-toxin monomer is controlled by several global regulatory systems [71]. The accessory gene regulator (agr) locus, codes for a quorum-sensing system that provides the primary control of Hla production via a regulatory RNA molecule, RNAIII [72,73]. Activated during late-log and stationary phases of growth, the agr system enables the production of the secreted autoinducer peptide (AIP). AIP binding to its cell surface, AgrC, activates its response regulator, AgrA [74,75]. AgrA binds to the P3 promoter of the agr locus and activates the production of the RNAIII molecule [76], culminating in the increased expression and secretion of hla with only $1 \%$ of total $\alpha$-toxin remaining cell-associated [73,77]. While this system provides the primary mechanism of regulation of hla, expression levels can also be modulated by both the Sae and Sar regulatory systems [78-81]. Despite the challenges associated with determining the contribution of these regulatory circuits in vivo, it is clear this complex interplay between these global regulators allows for the tight control of hla expression and likely facilitates a rapid yet specific response to changing environmental conditions.

\subsection{Host Cell Binding}

The molecular mechanism by which $\alpha$-toxin binds to the surface of host cell membranes had been a longstanding subject of debate in the field [17,18,82], as experimental evidence provided by multiple investigators either supported the ability of the toxin to bind to membrane lipids or to interact with host cells in a specific fashion consistent with proteinaceous receptor binding. Lending support to the former mechanism, (1) $\alpha$-toxin binds to artificial lipid membranes, and can perforate lipid vesicles leading to the release of intravesicular contents [52,66,83-89]; (2) the "rim-stem crevice" of the toxin directly interacts with membrane lipids [90]; (3) cholesterol depletion abrogates binding of $\alpha$-toxin to host cell membranes [82]; and (4) the addition of exogenous phosphocholine antagonizes toxin binding [82]. Further, multiple bacterial pore-forming cytotoxins utilize membrane lipids as their cellular receptors establishing a precedent for this mode of interaction [91]. These results, however, failed to explain the exquisite cell type and species specificity for $\alpha$-toxin binding and intoxication, highlighted by the drastic difference in susceptibility to Hla-mediated lysis between rabbit erythrocytes (with lysis occurring in the low nanomolar range) and human erythrocytes (with lysis occurring in the high nanomolar to low micromolar range) [18]. By performing detailed analysis of host cell binding using radioiodinated toxin, Cassidy and Harshman determined that $\alpha$-toxin binding to rabbit erythrocytes was saturable with a dissociation constant $\left(K_{\mathrm{d}}\right)$ of $6 \times 10^{-9}$ at $20^{\circ} \mathrm{C}$ [17]. They estimated approximately 5000 discrete toxin-binding sites per red cell, and therefore, argued for the existence of a high-affinity receptor for $\alpha$-toxin. This notion was extended by the findings of Hildebrand and colleagues indicating there are $\sim 1500-2000$ high-affinity "receptors" on sensitive cells, resulting in half-maximal toxin binding at $2 \mathrm{nM}$, while non-susceptible cells were subject to adsorptive binding of Hla with lysis observed only at high toxin concentrations [18].

For over a decade, the elusive nature of the proteinaceous toxin receptor coupled with the demonstrated ability of $\alpha$-toxin pores to form in a purified lipid membrane cast considerable doubt on the necessity or relevance of a protein dock on susceptible cells. Valeva and colleagues aimed to unite these seemingly disparate findings by hypothesizing that clustered phosphocholine headgroups serve as the high-affinity receptor for $\alpha$-toxin [82]. Their investigations revealed that treatment of cells with 
sphingomyelinase considerably diminished toxin binding, as did depletion of cellular cholesterol. Interesting recent observations on the role of $S$. aureus-elaborated membrane vesicles $(\mathrm{MV}$, akin to outer membrane vesicles described in Gram negative bacteria) indicate that $\alpha$-toxin can be delivered to the eukaryotic cell packaged in MVs, also requiring cholesterol in the target cell membrane to facilitate MV fusion and $\alpha$-toxin action [92,93].

While these findings failed to explain the observed species specificity of toxin action on erythrocytes, a lipid-receptor hypothesis comprised the prevailing thought in the field until a few years ago when ADAM10 was defined as a candidate proteinaceous receptor for $\alpha$-toxin [94]. Taking advantage of the differential susceptibility of rabbit and human erythrocytes to lysis, A Disintegrin And Metalloprotease 10 (ADAM10) was determined to be a proteinaceous receptor for $\alpha$-toxin, supported by the following: (1) ADAM10 is precipitated by Hla from the membrane of host cells; (2) ADAM10 is required for toxin binding and oligomerization; (3) the requirement for ADAM10 in Hla-mediated cytotoxicity is most apparent at low toxin concentrations wherein the need for a high-affinity cellular receptor was predicted to be most relevant [17]; and (4) the species specificity exhibited by $\alpha$-toxin was demonstrated to correlate with ADAM10 expression on rabbit erythrocytes, in contrast to its absence on the surface of the human red cell [94]. The observed interactions of $\alpha$-toxin with both membrane lipids and a proteinaceous receptor indicate the probable cooperativity of these interactions in modulation of toxin binding, assembly and cytotoxicity.

\subsection{Oligomerization and Pore Formation}

The transforming structural events that result in perforation of the host lipid bilayer by $\alpha$-toxin has been the study of intensive investigation, taking advantage of biochemical and structural analytic tools to define the movements of discrete protein segments into the membrane to generate the pore. $\alpha$-Toxin exhibits a well-defined pre-pore state, representing the fully assembled oligomeric structure on the host cell membrane. As the transition from monomeric toxin through the pre-pore state to the open pore has been the subject of extensive review within the structural biology field, we refer the reader to several excellent reviews $[36,95]$.

Several notable observations have arisen subsequent to these reviews, and have solidified a path that allows for structure-function insights to be utilized in the development of disease modifying strategies. The $\alpha$-toxin polypeptide does not contain any cysteine residues, a fact that has been capitalized on by a number of studies in which the introduction of cysteine residues has permitted both discrete site labeling for assessment of toxin structure and the generation of "locked" mutants that are unable to form membrane-inserted pores [96-98]. Valeva and colleagues determined that the $N$-terminal segment of $\alpha$-toxin undergoes a conformational shift to "latch" onto the neighboring protomer, stabilizing the heptameric pore structure [97]. The importance of the $N$-terminus was further demonstrated as the $\mathrm{His}_{35}$ residue precipitates the insertion of the stem domain into the membrane by moving into a hydrophobic environment at the pre-pore to pore transition [96]. Consequently, substitution mutants at this residue are unable to form a stable oligomer, and are thus incapable of assembly into a lytic pore in spite of their preservation of cellular binding ability [96,99-102]. Further underscoring the importance of the $N$-terminus in regulation of toxin assembly, a series of $N$-terminal 
truncation mutants encompassing up to the first 18 residues was consistent with a role for this portion of the protein in preventing the premature oligomerization of the monomeric toxin in solution [103].

Several lines of evidence illustrate the magnitude of the conformational change that occurs between the monomer-pore transition. Kawate and Gouaux engineered a tether between the pre-stem domain and the cap of the toxin by the incorporation of cysteine residues at amino acids 104 and 154 [98]. This molecule is "arrested" as a non-injurious heptameric pre-pore under oxiding conditions, resolving to a fully lytic pore under reducing conditions. Several years later, the structure of the water-soluble $\alpha$-toxin monomer was reported [104], providing further insight on the mechanism of conversion of the pre-pore to the assembled pore. While the small angle X-ray scattering technique utilized to obtain this structure suffers from low resolution, this technique was combined with molecular modeling to reveal that many features of the monomeric structure are conserved in the heptamer. The transitions from soluble monomeric toxin to the fully assembled pore are therefore discernable as distinct conformational entities, with the pre-pore to pore transition representing an irreversible molecular event. Several significant movements or regions of flexibility are noted in the transition process from monomeric toxin to the open pore, consistent with prior biochemical observations: (1) the rather dramatic down-folding of the central glycine-rich $\beta$-hairpin stem from each subunit ( $\left.\operatorname{Lys}_{100}-\mathrm{Tyr}_{148}\right)$ away from the monomer to perforate the membrane; (2) extension of the $N$-terminal segment $\left(\mathrm{Ala}_{1}-\mathrm{Val}_{20}\right)$ toward the neighboring protomer in the assembled heptamer, stabilizing the structure; and (3) flexibility of the phosphocholine binding region at the rim-stem interface [104]. These findings were supported by the recent demonstration of the structure of the $\alpha$-toxin monomer complexed to a neutralizing monoclonal antibody [105]. The wealth of insight derived from structure-function studies of pore formation has focused considerable interest on $\mathrm{His}_{35}$ and other non-toxinogenic mutants as candidates for vaccine development, as well as monoclonal antibody strategies that impede toxin action through specific effects on conformational changes that occur in the molecule or through blocade of toxin binding [105-108].

\section{Contribution of $\alpha$-Toxin to $S$. aureus Disease}

The Bundaberg accident and related investigations were the first of multiple studies to suggest that $\alpha$-toxin may play an important role in the pathogenesis of human disease, now primarily supported through two lines of evidence. First, carriers of $S$. aureus or individuals suffering from $S$. aureus disease develop serum antibody responses to the toxin consistent with toxin expression [26,27,109]. While these investigations do not provide a direct correlation between serum antibody titer and disease outcome, two recent studies begin to address this issue. Adhikari and colleagues examined a population of 100 adults at risk for $S$. aureus sepsis, revealing that the risk of sepsis was reduced in individuals with higher serum antibody titers to Hla and a collection of 4 other S. aureus toxins [109]. Fritz and colleagues examined serum anti-Hla responses in 235 children categorized in four cohorts - S. aureus colonized without evidence or history of infection, primary skin/soft tissue infection, recurrent skin/soft tissue infection, and invasive S. aureus disease. Children with invasive disease developed higher anti-Hla antibody titers, suggestive of toxin exposure. Of considerable interest, enrollees received one-year follow-up to examine the relationship between antibody titers and protection 
against $S$. aureus skin infection. Throughout the follow-up period, a statistically significant increase in anti-Hla titer correlated with protective immunity against recurrent infection [27].

Bacterial genetic and protein profiling analysis provides a second line of evidence implicating $\alpha$-toxin in the pathogenesis of human disease. The so-called "Phage-type $80 / 81$ " epidemic of the 1950 s and 1960s was notable for rampant and severe $S$. aureus disease in the population, afflicting individuals with an array of clinical manifestations of disease including skin/soft tissue infection, pneumonia, and sepsis/bacteremia [110-112]. Analysis of the hla and agr loci in these strains revealed the capability for $\alpha$-toxin expression, confirmed by a highly virulent phenotype of these isolates in animal studies of Hla-mediated disease [113]. In contrast, these investigators demonstrated that current hospital infection isolates (lineage EMRSA-16 and related clones that cluster in the same clonal complex) harbor point mutations in both loci, preventing $\alpha$-toxin production. These strains exhibit a corresponding decrease in virulence observed in animal models. Consistent with these findings, current epidemic USA300 isolates of $S$. aureus that cause a significant disease burden in healthy human hosts display both increased Hla expression and virulence in experimental models, dependent on the Agr and Sae regulatory systems that govern toxin expression [114-116]. In addition, $\alpha$-toxin expression was associated with non-resolution of bacterial peritonitis in individuals receiving peritoneal dialysis [117]. Together, these studies are most consistent with the conclusion that $\alpha$-toxin expression may be required for the pathogenesis of invasive disease in healthy individuals, while of lesser relevance in individuals that are already predisposed to invasive bacterial infection on account of underlying illness, hospitalization, or tissue barrier compromise in the setting of indwelling medical devices [113].

Advances in $S$. aureus genetic manipulation have allowed for perturbation of $\alpha$-toxin expression and a rigorous analysis of its role in the pathogenesis of disease in experimental animals. The use of toxin-deficient strains has highlighted the diversity of organs and tissue systems in which $\alpha$-toxin plays a significant role, as Hla-deficient mutants display reduced virulence in animal models of pneumonia [20,28], dermonecrotic skin infection [30,118], sepsis [13,119], peritonitis [118,120,121], and infection of the cornea [33], central nervous system [32], endocardium [122], and the mammary gland $[123,124]$.

While early studies alluded to the triad of lethal disease, hemolysis, and dermonecrosis as the chief manifestations of $\alpha$-toxin-induced host injury [14], clinical and disease modeling data highlight a considerable complexity of the role of $\alpha$-toxin in pathogenesis consistent with the ability of the toxin to cause injury and elicit cellular responses in a wide array of cell types (Figure 2). The discovery of ADAM10 as a cellular receptor for $\alpha$-toxin has allowed for a more thorough examination of the molecular mechanisms by which $\alpha$-toxin contributes to disease at the epithelial and endothelial tissue barriers [11-13]. These findings, along with substantial recent advances in our understanding of toxin-mediated regulation of host immunity [9,29,31,125-128], will be the subject of this section. 
Figure 2. Cellular responses to intoxication by Hla. Multiple cell types are targeted by $\alpha$-toxin, each displaying unique effects that are dependent on the relative concentration of toxin to which the cell is exposed.

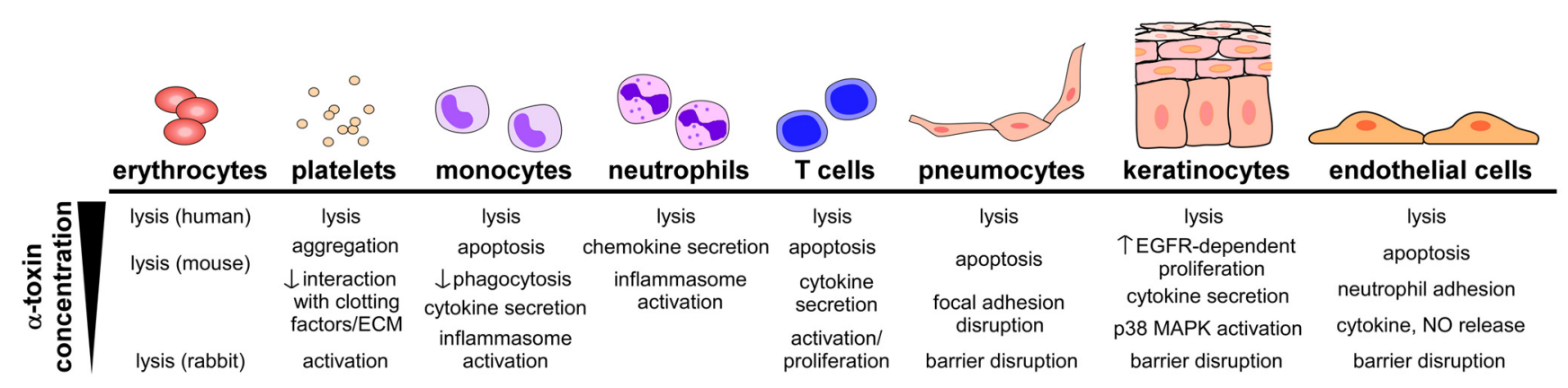

\subsection{Toxin-Induced Tissue Injury}

ADAM10, a cellular receptor for $\alpha$-toxin, is a zinc-dependent metalloprotease expressed as a type I transmembrane protein on the surface of a wide array of host cells $[129,130]$. The extracellular domain of ADAM10 is comprised of an $N$-terminal enzymatic domain followed by the so-called "disintegrin" and cysteine-rich domains, both of which may facilitate protein-protein interactions at the cell surface. The short cytoplasmic tail of ADAM10 encompasses a proline-rich sequence and a consensus binding site for calmodulin [131]. Functioning as a cellular "sheddase", ADAM10 is responsible for the cleavage of the ectodomains of a large number of host proteins including members of the cadherin family, epithelial growth factor, betacellulin, syndecans, chemokines, amyloid precursor protein (APP), platelet glycoprotein VI, notch, and ephrin, with substrate specificity varying by cell type [132-140]. Cleavage by ADAM10 leads to ectodomain release from the cell surface and the retention of a membrane-bound fragment, which is subject to further proteolytic processing. ADAM10-mediated cleavage yields discrete biologic outcomes, as many extracellular and intracellular cleavage products are active signaling moieties that facilitate both physiologic and pathophysiologic processes.

The requirement for ADAM10 as a cellular receptor for $\alpha$-toxin in $S$. aureus pathogenesis was recently demonstrated utilizing conditional knockout approaches in the alveolar epithelium and the mature epidermis [11,12]. Germline deletion of ADAM10 results in embryonic lethality at E9.5 [141], and is associated with cell-specific abnormalities upon conditional knockout the developing epidermis, neuronal progenitor cells, the endothelium, and several hematopoietic lineage cells [142-147]. The loss of ADAM10 expression in the lung led to a marked improvement in the outcome of $S$. aureus pneumonia [11], minimizing lethal disease as compared to control mice. Similarly, ADAM10 knockout in the skin was associated with a reduction in the size of $S$. aureus skin lesions and abrogation of the severe dermonecrotic tissue injury that is a hallmark of the action of $\alpha$-toxin [12].

A number of studies indicate that $\alpha$-toxin induces signaling events in the target cell (Figure 2). The small pore formed by the toxin permits the rapid release of ATP, $\mathrm{K}^{+}$ions (or ${ }^{86} \mathrm{Rb}^{+}, \mathrm{a} \mathrm{K}^{+}$ analogue) [17,128,148], however, restricts the movement of macromolecules across the cell membrane. One of the early and perhaps most important, cellular events following toxin pore formation is the influx of extracellular calcium into the cell. As a central trigger of cell signaling pathways, increased intracellular calcium stimulates hydrolysis of membrane phospholipids and 
metabolism of arachadonic acid to leukotrienes, prostanoids, and thromboxane A2 [21,149,150]. Toxin treatment also leads to the generation of nitric oxide in endothelial and epithelial cells, activation of protein kinase $\mathrm{C}$, and induction of NF- $\kappa \mathrm{B}$ nuclear translocation [21,150,151]. Together, these events signify the pro-inflammatory stimulus evoked by intoxication, also evident by cellular production of IL-1 $\beta$, IL-6, and IL-8 [148,150]. These inflammatory stimuli, as well as associated cell death via pyroptosis, can exert a marked impact on the local tissue microenvironment, stimulating immune cell recruitment, increasing reactivity of the vasculature, promoting tissue edema, and modulating host immunity (further discussed in Section 4.2 below) [9,152-154]. It is attractive to hypothesize that one or more domains of ADAM10, particularly the transmembrane domain or cytoplasmic tail of the molecule, may contribute to toxin-induced intracellular signaling. This and other facets of the Hla-ADAM10 interaction remain to be explored through perturbation of ADAM10 in both the cellular and tissue context.

In the context of epithelial cells (such as pneumocytes and keratinocytes) that are key targets of $\alpha$-toxin, E-cadherin is a principal substrate for ADAM10 [133,155]. Cleavage of E-cadherin by ADAM10 results in a loss of the homotypic interaction of the cadherin molecules on adjacent cells at the adherens junction, thereby injuring the epithelial tissue barrier function. In vitro studies demonstrated the surprising finding that treatment of epithelial cells with sublytic concentrations of $\alpha$-toxin leads to a rapid upregulation of the metalloprotease activity of ADAM10, which in turn dismantled the adherens junction through cleavage of E-cadherin [11,12]. Extension of these studies in the context of infection revealed that $\alpha$-toxin caused a primary disturbance of the epithelial barrier in the lung and the skin, manifesting as proteinaceous pulmonary edema and dermonecrotic injury, respectively. In both of these tissues, the $\alpha$-toxin-ADAM10 complex was demonstrated to mediate E-cadherin cleavage in vivo, correlating with the physiologic evidence of epithelial injury observed during infection. These findings prompted examination of the molecular mechanism that underlies toxin-induced ADAM10 metalloprotease activation. Activation occurs at subcytolytic concentrations of $\alpha$-toxin [11-13], however requires the formation of a fully assembled, patent heptameric pore on the surface of the cell. Three lines of evidence support this mechanism of activation: (1) the $\mathrm{Hla}_{\mathrm{H} 35 \mathrm{~L}}$ mutant is unable to trigger ADAM10 activation-while this toxin variant displays normal ADAM10 binding [94], it is unable to form a stable oligomer on the cell surface and therefore is non-lytic [100]; (2) a "pre-pore locked" mutant harboring an engineered disulfide bond that tethers the stem domain to the globular cap, precluding insertion of the stem through the plasma membrane under oxidizing conditions, only causes ADAM10 activation in the presence of a reducing agent [11]; and (3) methyl- $\beta$-cyclodextrin, a small molecule that inserts into the open toxin pore, providing functional blockade of the pore, abrogates ADAM10 activation [11]. While the specific molecular mechanism of ADAM10 activation by $\alpha$-toxin is not yet elucidated, the observed requirement for calcium in the extracellular media of toxin-treated cells is highly suggestive that the toxin pore functions as an ion channel permitting the influx of calcium into the cell [11]. It is known that ionophore treatment of cells provides a stimulus for activation of ADAM10 [140,156], likely through an "inside-out" signal relay. While the cytoplasmic domain of ADAM10 would seemingly be implicated in this signaling mechanism, deletion of this domain of ADAM10 does not fully impair ionophore-mediated ADAM10 activation [140], implying that other domains of the protein and possibly other signal transduction proteins play a cooperative role in ADAM10 activation. 
Beyond the contribution of ADAM10-mediated cleavage of structural proteins that provide tensile strength to the tissue barrier, the $\alpha$-toxin-ADAM10 interaction leads to the rapid dephosphorylation of FAK, paxillin, Src, and p130Cas, proteins integral to the establishment and maintenance of cellular focal adhesions that tether the cell to the basement membrane [94]. These cell signaling events are associated with dissolution of focal adhesions, defining a second molecular mechanism by which $\alpha$-toxin contributes to tissue barrier disruption. Like ADAM10-mediated cadherin cleavage, focal adhesion disruption is observed at subcytolytic toxin concentrations, suggesting that an intracellular signal transduction cascade is potentially invoked. Together with data on the role of membrane lipids and ADAM10 in toxin binding, an integrated model can now be considered in which assembly of a multi-molecular protein receptor and signaling complex in a specific lipid microenvironment is required for optimal action of $\alpha$-toxin.

Tissue barrier disruption is a hallmark of staphylococcal disease, manifest as injury to the skin, lung, mucous membranes, and vasculature (in the context of sepsis). Inoculation of $\alpha$-toxin into the lungs of rabbits caused endothelial cell lysis and detachment from the basal membrane leading to endothelial barrier permeability and vascular leakage into the alveolar space [152]. In agreement with these observations, treatment of pulmonary endothelial cells with $\alpha$-toxin induced the formation of large intercellular gaps associated with a decrease in barrier integrity [154]. Recent studies provide molecular insight on the nature of endothelial barrier disruption, demonstrating that $\alpha$-toxin binding to ADAM10 on primary endothelial cells leads to rapid activation of the metalloprotease and cleavage of vascular endothelial (VE)-cadherin [13]. Toxin-deficient $S$. aureus strains display a virulence defect in a mouse model of lethal sepsis induced by intravenous inoculation of the pathogen; this correlates with toxin-mediated induction of endovascular injury and increased vascular permeability, as documented by dye extravasation studies [13].

These observations hearken back to the early studies on the role of Hla in lethal disease and dermonecrotic injury, now providing molecular detail of $\alpha$-toxin action in these states of host injury. It becomes clear that the functional outcome of the toxin-ADAM10 interaction is predicated both on the Hla-induced cell lysis and cell signaling, as well as on the tissue-specific actions of activated ADAM10 (Figure 3). The pleiotropic effects of a single toxin can, therefore, now be explained by three principles: (1) targeting of multiple host cell types through widespread expression of ADAM10; (2) cell-specific susceptibility to pore formation; and (3) diversity of cellular effects of the toxin dependent on the level of ADAM10 expression, the native functions of ADAM10 in the cell/tissue, and the intracellular signaling events elicited in the cell. Importantly, each of these outcomes are absolutely dependent on the assembly and patency of the $\alpha$-toxin pore [11], demonstrating the primacy of the $\beta$-PFT structure for the full range of the toxin's biologic activity. 
Figure 3. Dual mechanism of action of $\alpha$-toxin on susceptible host cells. Model illustrating key functions of the $\alpha$-toxin (red)-ADAM10 (blue) complex, facilitating membrane binding of the toxin with subsequent oligomerization and pore formation. The formation of the toxin pore leads to two functionally linked outcomes-induction of host cell signaling and/or cellular lysis (dependent on toxin concentration) and the rapid upregulation of the metalloprotease activity of ADAM10 (denoted by a star). ADAM10, in turn, acts in a cell-specific manner to cleave ectodomain-containing proteins (orange) that appear to represent important biological mediators of $\alpha$-toxin action.

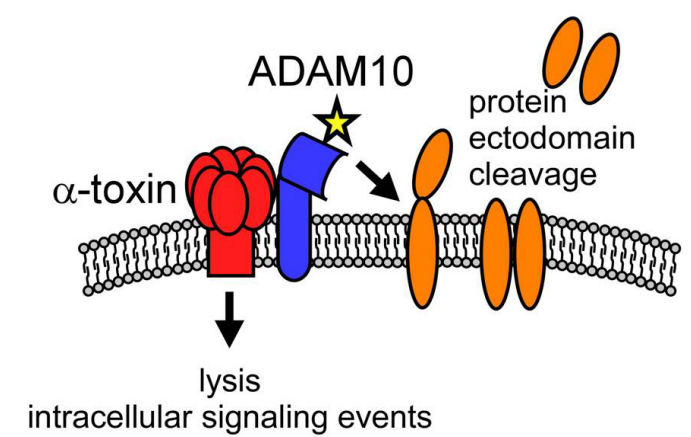

\subsection{Toxin-Induced Immunomodulation}

Multiple studies have indicated that immune cells are targets of $\alpha$-toxin. While of interest, these studies have not yet led to a full appreciation for the role of the toxin in manipulating the immune response in vivo to facilitate pathogenesis. In recent years, several key studies have shed light on this topic, illustrating that $\alpha$-toxin targets both innate and adaptive immune cells, altering the host response to staphylococcal infection and again demonstrating the diverse capabilities of the toxin.

Pro-inflammatory signaling in the host in response to infection is a double-edged sword, affording protection from pathogens yet contributing to self-injury when overly robust. Inflammation is a key feature of $S$. aureus infection, most readily appreciated in the lungs and skin wherein the rapid infiltration of innate immune cells is observed in both human and murine hosts [157-159]. In murine pneumonia, $\alpha$-toxin is required to generate a gradient of keratinocyte-derived chemokine (KC) and macrophage inflammatory protein-2 (MIP-2), CXC chemokines that facilitate neutrophil recruitment to the lung [160]. $\alpha$-toxin induces inflammatory responses in multiple cells, resulting in the release of cytokines and vasoactive agents [21,148-151,161,162]. One hallmark of innate immune cell activation

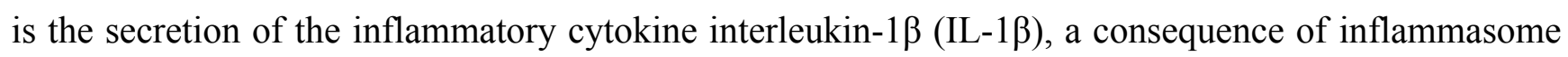
activation and caspase-mediated cleavage of pro-IL-1 $\beta$ to yield the active cytokine. Intoxication with $\alpha$-toxin induces IL- $1 \beta$ secretion in macrophages and monocytes, implicating this lineage as a target of the toxin during infection and demonstrating the importance of inflammatory cell death in disease pathogenesis $[9,31,148]$. Craven and colleagues demonstrated that the nucleotide binding domain and leucine rich repeat containing gene family, pyrin domain containing protein (NLRP3) inflammasome was activated in monocytic cells following exposure to $\alpha$-toxin, resulting in caspase- 1 activation and IL-1 $\beta$ secretion [9]. While antagonism of the toxin in vivo through toxin-neutralizing antibodies blunted IL-1 $\beta$ secretion during $S$. aureus pneumonia [116], the molecular mechanisms underlying this response in vivo had not been investigated until recently. Following on the work of Craven, Kebaier 
and colleagues demonstrated toxin-dependent activation of the NLRP3 inflammasome in S. aureus pneumonia, leading to necrotic tissue injury [31]. Consistent with these findings, an attenuation of disease was observed in mice harboring germline deletion of Nlrp3. Mice lacking expression of NLRP3 display increased survival following intratracheal instillation of purified $\alpha$-toxin, and show decreased lung pathology, IL-1 $\beta$ secretion and neutrophilic infiltrates upon infection with live staphylococci. These studies strongly implicate the role of NLRP3 and this inflammatory cascade as downstream effectors of $\alpha$-toxin-mediated pathogenesis, linking this pathway to toxin-induced cell death that is most consistent with pyroptosis $[9,163]$. Interestingly, while antagonism of $\alpha$-toxin by active vaccination, passive immunization, and direct small molecule inhibitors decreases the bacterial load in the lung during infection [107,116,164], mice harboring a deletion of either Nlrp3 or conditional deletion of Adam10 in the alveolar epithelium do not display a decreased bacterial burden following infection [11,31].

Illustrating the complexity of the host-pathogen interaction in distinct tissues, the induction of an IL-1 $\beta$ response to $S$. aureus skin infection is required for host immunoprotection, as mice lacking the ability to generate this inflammatory response through genetic deletion of the cytokine or its cellular receptor suffer exacerbated skin lesions in response to inoculation with $S$. aureus $[10,165]$. The establishment of an immunoprotective IL- $1 \beta$ response in the skin depends on neutrophil recruitment to the infection site, and elaboration of this cytokine by the neutrophil population [10]. $\alpha$-toxin neutralizing antibodies significantly decrease the amount of IL-1 $\beta$ secreted by isolated mouse neutrophils exposed to Hla in vitro, suggesting that the toxin in part contributes to this beneficial inflammatory host response in the skin [10]. Taken together, these data illustrate the role of Hla in inflammasome activation, and highlights the dichotomy between the beneficial effect of this pro-inflammatory response to infection of the skin and the detrimental effect of toxin-mediated inflammation in the lung. Interestingly, antagonism of Hla by active or passive immunization affords protection in both the lung and the skin [30,107,108,116], highlighting the existing challenges in the field to understand how distinct cellular responses to $\alpha$-toxin are integrated in the context of the tissue microenvironment during infection.

In addition to these effects on innate immunity, there is growing evidence that $\alpha$-toxin modulates the adaptive immune response. Patterning of adaptive immune responses have been noted to occur through two mechanisms: (1) direct cellular injury, wherein $\alpha$-toxin induces apoptotic cell death in monocytes, B cells and T cells [22]; and (2) through alteration of signaling between innate and adaptive immune cells, particularly via the cytokine interleukin 17A (IL-17A). Treatment of human monocytes with subcytolytic concentrations of $\alpha$-toxin stimulates secretion of IL-17A [166]. This cytokine polarizes the helper $\mathrm{T}$ cell response towards the induction of $\mathrm{Th} 17$ cells, a subset of $\mathrm{CD} 4^{+} \mathrm{T}$ cells that both respond to and express IL-17A, and contribute most notably to immunoprotection of the epithelium. The Th17 response has been implicated in both the immunopathogenesis of toxin-mediated inflammatory skin disease and in protection against acute infection [159,166,167]. Frank and colleagues recently used a whole-transcriptome approach to discern the effect of $\alpha$-toxin on the host response to $S$. aureus pneumonia. This study compared responses in mice infected with wild-type $S$. aureus to those infected with toxin-deficient $S$. aureus in a murine disease model, demonstrating that toxin expression was associated with induction of the IL-17A response [29]. Mice infected with $\alpha$-toxin-expressing $S$. aureus generate a T cell repertoire characterized by a greater number of IL-17A ${ }^{+}$ 
cells, illustrating a direct impact of the toxin on the adaptive immune system. While the precise molecular mechanisms that underlie induction of the polarized Th17 response are not yet known, the nucleotide-binding oligomerization domain containing 2 (NOD2) has been shown to play an important role in mediating innate immunodefense against $S$. aureus, as $\mathrm{NOD}^{-/-}$mice exhibit increased susceptibility to both intraperitoneal and subcutaneous $S$. aureus infection [127,168]. NOD2 functions as an intracellular receptor for peptidoglycan (PGN), thus the $\alpha$-toxin pore is thought to enhance cytosolic access for this NOD2 ligand [127]. As NOD2 signaling can promote Th17 differentiation [169], this represents a plausible pathway for further investigation.

While many of these observations suggest that the toxin's harmful actions are unopposed by the host, epithelial cells are able to repair toxin-induced membrane injury and eliminate the toxin through a linked process of endocytosis from the membrane and exocytosis of the toxin in so-called "toxosomes", or exosome-like vesicles [170-172]. Further, type-I interferon (IFN) produced by the host can afford protection against toxin-induced injury [126]. This effect is dependent on the presence of phospholipid scramblase I (PLSCR1), which provides protection against cellular leakage of ATP [128]. While the precise mechanisms of action of PLSCR1 are not yet elucidated, strong support for the role of this protein in host protection against $\alpha$-toxin is observed in PLSCR1 knockout mice that demonstrate increased susceptibility to the injurious actions of the toxin in the lung [128]. The alteration of innate immune signaling pathways and the discovery of the ability of $\alpha$-toxin to directly modulate the adaptive response is thus an exciting area of current research.

\section{Conclusions and Future Directions}

While $S$. aureus $\alpha$-toxin has been among the most-studied bacterial cytotoxins, consideration of the knowledge gained over nearly a century of research highlights the extraordinary complexity of toxin function and illustrates many avenues for future investigation. The discovery of ADAM10 as a cellular receptor for $\alpha$-toxin provides a number of opportunities to probe the biology of the toxin, enabling a focused examination of the effects of the toxin on specific cell populations in the context of disease. The broad expression pattern of ADAM10 raises several interesting areas for ongoing study that are necessary to define the principles that govern cell specificity of toxin action. We put forth several hypotheses in this regard: (1) the level of ADAM10 expressed on distinct primary cells may differ, forming the basis for relative susceptibility to $\alpha$-toxin. This model is most consistent with existing data in the field noting a correlation between cell surface expression of ADAM10 and toxin-mediated lysis; (2) Cell specificity of $\alpha$-toxin action is conferred by ADAM10 in concert with other proteins that display unique expression patterns, thereby providing some restriction to either toxin binding (such as a co-receptor) or susceptibility to lysis or ADAM10 activation (modulation of cell injury and signaling events); (3) Sensitivity to $\alpha$-toxin may depend on ADAM10 expression as the cellular receptor in certain primary cell populations, while a distinct cellular receptor may exist on other cell populations. While the central role of ADAM10 expression has been confirmed in several epithelial tissues, primary endothelium, and red blood cells, further studies utilizing cell-type specific ADAM10 knockout approaches are anticipated to enable the most clear-cut investigation of this hypothesis. Importantly, this approach will not only examine the role of ADAM10 across distinct 
tissues, but will enable essential paired investigations on the role of the $\alpha$-toxin-ADAM10 complex in disease pathogenesis.

It is anticipated that further study of the toxin-ADAM10 complex will provide insight on the specific nature of the protein and lipid microenvironment that allows for toxin binding, assembly and host cellular signaling events generated during intoxication, enable investigation of human genetic polymorphisms that may increase susceptibility to disease, and facilitate studies of how Hla and other staphylococcal virulence factors act in concert to cause infection. As a number of studies in the field have highlighted features of cellular susceptibility to $\alpha$-toxin in vitro, it will be essential to critically examine these observations in vivo, defining the molecular mechanisms of $\alpha$-toxin-ADAM10 function and the role of other protein machinery in the context of $S$. aureus disease states. While of immediate relevance to our understanding of $S$. aureus disease, these studies will likely impact more broadly on our knowledge of pore-forming toxins and potentially highlight novel strategies to interfere with this family of toxins.

Research over the last few years has led to a significant increase in our understanding of the role of $\alpha$-toxin in the molecular pathogenesis of $S$. aureus disease. A tangible outcome of these studies is an appreciation of this toxin as a leading target for disease-modifying therapies, and has engendered an increased focus on understanding the role of the toxin in human $S$. aureus infection. Vaccines, passive immunization strategies, small molecule inhibitors of the toxin, and most recently small molecule-based targeting of host ADAM10 have all demonstrated a degree of efficacy in combatting S. aureus disease in animal modeling systems [11-13,30,105,108,116,119,121,164,173-177]. As such, many of these modalities are being developed for, and examined in, human clinical trials. The successful implementation of these preventatives and therapeutics will require an integrated understanding of the molecular pathogenesis of $\alpha$-toxin-induced disease, the human clinical infection states in which Hla is essential, and an appreciation of the human immunologic responses that confer protection against toxin-mediated injury. Building on our wealth of knowledge about $\alpha$-toxin, it now becomes a realistic expectation that modification of toxin-mediated $S$. aureus disease will be achieved in the coming years.

\section{Acknowledgements}

This work was supported by the Depts. of Pediatrics and Microbiology at the Univ. of Chicago, NIH award AI097434-01, and the Burroughs Wellcome Foundation through an Investigators in the Pathogenesis of Infectious Disease Fellowship to J.B.W. The authors also acknowledge membership in and support from the Region V "Great Lakes" RCE (NIH award 2-U54-AI-057153). B.B. was partially supported by NIH Grant T32 GM007183.

\section{Conflict of Interest}

J.B.W. has the potential to receive royalties from Novartis Vaccines and Diagnostics in relation to patents owned by the University of Chicago. 


\section{References}

1. Bhakdi, S.; Tranum-Jensen, J. Alpha-toxin of Staphylococcus aureus. Microbiol. Rev. 1991, 55, 733-751.

2. Van der Goot, F.G.E. Pore Forming Toxins; Springer Verlag: Berlin, Germany, 2001.

3. Prevost, G.; Mourey, L.; Colin, D.; Monteil, H.; Dalla Serra, M.; Menestrina, G. Alpha-helix and Beta-barrel Pore-forming Toxins (Leucocidins, alpha-, gamma-, and delta-cytolysins) of Staphylococcus aureus. In The Comprehensive Sourcebook of Bacterial Toxins; Alouf, J.E., Freer, J.H., Eds.; Academic Press: London, UK, 2005; pp. 590-607.

4. Parker, M.W.; Feil, S.C. Pore-forming protein toxins: From structure to function. Prog. Biophys. Mol. Biol. 2005, 88, 91-142.

5. Song, L.; Hobaugh, M.R.; Shustak, C.; Cheley, S.; Bayley, H.; Gouaux, J.E. Structure of staphylococcal alpha-hemolysin, a heptameric transmembrane pore. Science 1996, 274, 1859-1866.

6. Gouaux, J.E.; Braha, O.; Hobaugh, M.R.; Song, L.; Cheley, S.; Shustak, C.; Bayley, H. Subunit stoichiometry of staphylococcal alpha-hemolysin in crystals and on membranes: A heptameric transmembrane pore. Proc. Natl. Acad. Sci. USA 1994, 91, 12828-12831.

7. Bhakdi, S.; Walev, I.; Hussmann, M.; Valeva, A. Staphylococcal Alpha-Toxin. In Microbial Protein Toxins; Schmitt, M.J., Schaffrath, R., Eds.; Springer-Verlag: Berlin, Germany, 2005.

8. Haugwitz, U.; Bobkiewicz, W.; Han, S.R.; Beckmann, E.; Veerachato, G.; Shaid, S.; Biehl, S.; Dersch, K.; Bhakdi, S.; Husmann, M. Pore-forming Staphylococcus aureus alpha-toxin triggers epidermal growth factor receptor-dependent proliferation. Cell Microbiol. 2006, 8, 1591-1600.

9. Craven, R.R.; Gao, X.; Allen, I.C.; Gris, D.; Bubeck Wardenburg, J.; McElvania-Tekippe, E.; Ting, J.P.; Duncan, J.A. Staphylococcus aureus alpha-hemolysin activates the nlrp3-inflammasome in human and mouse monocytic cells. PLoS One 2009, 4, e7446.

10. Cho, J.S.; Guo, Y.; Ramos, R.I.; Hebroni, F.; Plaisier, S.B.; Xuan, C.; Granick, J.L.; Matsushima, H.; Takashima, A.; Iwakura, Y.; et al. Neutrophil-derived il-1beta is sufficient for abscess formation in immunity against Staphylococcus aureus in mice. PLoS Pathog. 2012, 8, e1003047.

11. Inoshima, I.; Inoshima, N.; Wilke, G.A.; Powers, M.E.; Frank, K.M.; Wang, Y.; Bubeck Wardenburg, J. A Staphylococcus aureus pore-forming toxin subverts the activity of adam10 to cause lethal infection in mice. Nat. Med. 2011, 17, 1310-1314.

12. Inoshima, N.; Wang, Y.; Wardenburg, J.B. Genetic requirement for adam10 in severe Staphylococcus aureus skin infection. J. Invest. Dermatol. 2012, 132, 1513-1516.

13. Powers, M.E.; Kim, H.K.; Wang, Y.; Bubeck Wardenburg, J. Adam10 mediates vascular injury induced by Staphylococcus aureus alpha-hemolysin. J. Infect. Dis. 2012, 206, 352-356.

14. Burnet, F.M. The exotoxins of Staphylococcus pyogenes aureus. J. Pathol. Bacteriol. 1929, 32 , 717-734.

15. Burnet, F.M. The production of staphylococcal toxin. J. Pathol. Bacteriol. 1930, 33, 1-16.

16. Cassidy, P.S.; Harshman, S. The binding of staphylococcal ${ }^{125}$ I-alpha-toxin (b) to erythrocytes. J. Biol. Chem. 1973, 248, 5545-5546.

17. Cassidy, P.; Harshman, S. Studies on the binding of staphylococcal ${ }^{125}$ I-labeled alpha-toxin to rabbit erythrocytes. Biochemistry 1976, 15, 2348-2355. 
18. Hildebrand, A.; Pohl, M.; Bhakdi, S. Staphylococcus aureus alpha-toxin. Dual mechanism of binding to target cells. J. Biol. Chem. 1991, 266, 17195-17200.

19. Siegel, I.; Cohen, S. Action of staphylococcal toxin on human platelets. J. Infect. Dis. 1964, 114, 488-502.

20. Bubeck Wardenburg, J.; Patel, R.J.; Schneewind, O. Surface proteins and exotoxins are required for the pathogenesis of Staphylococcus aureus pneumonia. Infect. Immun. 2007, 75, 1040-1044.

21. Grimminger, F.; Rose, F.; Sibelius, U.; Meinhardt, M.; Potzsch, B.; Spriestersbach, R.; Bhakdi, S.; Suttorp, N.; Seeger, W. Human endothelial cell activation and mediator release in response to the bacterial exotoxins Escherichia coli hemolysin and staphylococcal alpha-toxin. J. Immunol. 1997, 159, 1909-1916.

22. Nygaard, T.K.; Pallister, K.B.; DuMont, A.L.; DeWald, M.; Watkins, R.L.; Pallister, E.Q.; Malone, C.; Griffith, S.; Horswill, A.R.; Torres, V.J.; et al. Alpha-toxin induces programmed cell death of human T cells, B cells, and monocytes during USA300 infection. PLoS One 2012, 7, e36532.

23. Manohar, M.; Maheswaran, S.K.; Frommes, S.P.; Lindorfer, R.K. Platelet damaging factor, a fifth activity of staphylococcal alpha-toxin. J. Bacteriol. 1967, 94, 224-231.

24. Bhakdi, S.; Muhly, M.; Mannhardt, U.; Hugo, F.; Klapettek, K.; Mueller-Eckhardt, C.; Roka, L. Staphylococcal alpha toxin promotes blood coagulation via attack on human platelets. J. Exp. Med. 1988, 168, 527-542.

25. Holtfreter, S.; Nguyen, T.T.H.; Wertheim, H.; Steil, L.; Kusch, H.; Truong, Q.P.; Engelmann, S.; Hecker, M.; Volker, U.; van Belkum, A.; et al. Human immune proteome in experimental colonization with Staphylococcus aureus. Clin. Vaccine Immunol. 2009, 16, 1607-1614.

26. Kolata, J.; Bode, L.G.; Holtfreter, S.; Steil, L.; Kusch, H.; Holtfreter, B.; Albrecht, D.; Hecker, M.; Engelmann, S.; van Belkum, A.; et al. Distinctive patterns in the human antibody response to Staphylococcus aureus bacteremia in carriers and non-carriers. Proteomics 2011, 11, 3914-3927.

27. Fritz, S.A.; Tiemann, K.M.; Hogan, P.G.; Epplin, E.K.; Rodriguez, M.; Al-Zubeidi, D.N.; Bubeck Wardenburg, J.; Hunstad, D.A. A serologic correlate of protective immunity against community-onset Staphylococcus aureus infection. Clin. Infect. Dis. 2013, 56, 1554-1561.

28. Bubeck Wardenburg, J.; Bae, T.; Otto, M.; Deleo, F.R.; Schneewind, O. Poring over pores: Alpha-hemolysin and panton-valentine leukocidin in Staphylococcus aureus pneumonia. Nat. Med. 2007, 13, 1405-1406.

29. Frank, K.M.; Zhou, T.; Moreno-Vinasco, L.; Hollett, B.; Garcia, J.G.; Bubeck Wardenburg, J. Host response signature to Staphylococcus aureus alpha-hemolysin implicates pulmonary th17 response. Infect. Immun. 2012, 80, 3161-3169.

30. Kennedy, A.D.; Bubeck Wardenburg, J.; Gardner, D.J.; Long, D.; Whitney, A.R.; Braughton, K.R.; Schneewind, O.; DeLeo, F.R. Targeting of alpha-hemolysin by active or passive immunization decreases severity of USA300 skin infection in a mouse model. J. Infect. Dis. 2010, 202, 1050-1058. 
31. Kebaier, C.; Chamberland, R.R.; Allen, I.C.; Gao, X.; Broglie, P.M.; Hall, J.D.; Jania, C.; Doerschuk, C.M.; Tilley, S.L.; Duncan, J.A. Staphylococcus aureus alpha-hemolysin mediates virulence in a murine model of severe pneumonia through activation of the nlrp3 inflammasome. J. Infect. Dis. 2012, 205, 807-817.

32. Kielian, T.; Cheung, A.; Hickey, W.F. Diminished virulence of an alpha-toxin mutant of Staphylococcus aureus in experimental brain abscesses. Infect. Immun. 2001, 69, 6902-6911.

33. O’Callaghan, R.J.; Callegan, M.C.; Moreau, J.M.; Green, L.C.; Foster, T.J.; Hartford, O.M.; Engel, L.S.; Hill, J.M. Specific roles of alpha-toxin and beta-toxin during Staphylococcus aureus corneal infection. Infect. Immun. 1997, 65, 1571-1578.

34. Arbuthnott, J.P. Staphylococcal Alpha-toxin. In Microbial Toxins; Montie, T.C., Kadis, S., Ajl, S.I., Eds.; Academic Press: New York, NY, USA, 1970; Volume III, pp. 189-236.

35. Wiseman, G.M. The hemolysins of Staphylococcus aureus. Bacteriol. Rev. 1975, 39, 317-344.

36. Gouaux, E. Alpha-hemolysin from Staphylococcus aureus: An archetype of beta-barrel, channel-forming toxins. J. Struct. Biol. 1998, 121, 110-122.

37. De Christmas, M.J. Recherches expérimentales sur la suppuration. Ann. Inst. Pasteur 1888, 2, 469.

38. Von Leber, T. Uber die entstehung der entzundung und die wirkung der entzundungserregenden schadlichkeiten. Fortschr. Med. 1888, 6, 460.

39. Breiger, L.; Fraenkel, C. Untersuchungen uber bacteriengifte. Berlin Klin. Wochschr. 1890, 27, 241.

40. Rodet, A.; Courmont, J. Produits du staphylocoque pyogène. Bull. Med. 1892, 23, 84.

41. Van de Velde, H. Mécanisme de la virulence du staphylocoque pyogène. Cellule 1894, 10, 401.

42. Neisser, M.; Wechsberg, F. Ueber das staphylotoxin. Z. Hyg. Infektionskrankh 1901, 36, 299.

43. Kraus, R.; Pribram, E. Ueber staphylokokkentoxin und dessen antitoxin. Wien. Klin. Wochschr. 1906, 17, 493.

44. Royal Commission of Inquiry into Fatalities at Bundaberg. Report of the Royal Commission of Inquiry into Fatalities at Bundaberg, Together with Appendices; Green, H.J., Ed.; Government Printer: Melbourne, Australia, 1928.

45. Elek, S.D. Staphylococcus Pyogenes; E. and S. Livingstone, Ltd.: Edinburgh, UK, 1959.

46. Glenny, A.T.; Stevens, M.F. Staphylococcus toxins and antitoxins. J. Pathol. Bacteriol. 1935, 40, 201-210.

47. Cooper, L.Z.; Madoff, M.A.; Weinstein, L. Heat stability and species range of purified staphylococcal alpha-toxin. J. Bacteriol. 1966, 91, 1686-1692.

48. Bernheimer, A.W.; Avigad, L.S.; Grushoff, P. Lytic effects of staphylococcal alpha-toxin and delta-hemolysin. J. Bacteriol. 1968, 96, 487-491.

49. Cooper, L.Z.; Madoff, M.A.; Weinstein, L. Hemolysis of rabbit erythrocytes by purified staphylococcal alpha-toxin. I. Kinetics of the lytic reaction. J. Bacteriol. 1964, 87, 127-135.

50. Kumar, S.; Lindorfer, R.K. The characterization of staphylococcal toxins. I. The electrophoretic migration of the alpha hemolytic, dermonecrotic, lethal, and leucocidal activities of crude toxin. J. Exp. Med. 1962, 115, 1095-1106.

51. Bernheimer, A.W.; Schwartz, L.L. Isolation and composition of staphylococcal alpha toxin. J. Gen. Microbiol. 1963, 30, 455-468. 
52. Weissmann, G.; Sessa, G.; Bernheimer, A.W. Staphylococcal alpha-toxin: Effects on artificial lipid spherules. Science 1966, 154, 772-774.

53. Thelestam, M.; Mollby, R.; Wadstrom, T. Effects of staphylococcal alpha-, beta-, delta-, and gamma-hemolysins on human diploid fibroblasts and hela cells: Evaluation of a new quantitative as say for measuring cell damage. Infect. Immun. 1973, 8, 938-946.

54. Thelestam, M.; Mollby, R. Sensitive assay for detection of toxin-induced damage to the cytoplasmic membrane of human diploid fibroblasts. Infect. Immun. 1975, 12, 225-232.

55. Thelestam, M.; Mollby, R. Determination of toxin-induced leakage of different-size nucleotides through the plasma membrane of human diploid fibroblasts. Infect. Immun. 1975, 11, 640-648.

56. Fussle, R.; Bhakdi, S.; Sziegoleit, A.; Tranum-Jensen, J.; Kranz, T.; Wellensiek, H.J. On the mechanism of membrane damage by Staphylococcus aureus alpha-toxin. J. Cell Biol. 1981, 91, 83-94.

57. Freer, J.H.; Arbuthnott, J.P.; Bernheimer, A.W. Interaction of staphylococcal alpha-toxin with artificial and natural membranes. J. Bacteriol. 1968, 95, 1153-1168.

58. Kehoe, M.; Duncan, J.; Foster, T.; Fairweather, N.; Dougan, G. Cloning, expression, and mapping of the Staphylococcus aureus alpha-hemolysin determinant in Escherichia coli k-12. Infect. Immun. 1983, 41, 1105-1111.

59. Fairweather, N.; Kennedy, S.; Foster, T.J.; Kehoe, M.; Dougan, G. Expression of a cloned Staphylococcus aureus alpha-hemolysin determinant in Bacillus subtilis and Staphylococcus aureus. Infect. Immun. 1983, 41, 1112-1117.

60. Gray, G.S.; Kehoe, M. Primary sequence of the alpha-toxin gene from Staphylococcus aureus Wood 46. Infect. Immun. 1984, 46, 615-618.

61. Tweten, R.K.; Christianson, K.K.; Iandolo, J.J. Transport and processing of staphylococcal alpha-toxin. J. Bacteriol. 1983, 156, 524-528.

62. Tobkes, N.; Wallace, B.A.; Bayley, H. Secondary structure and assembly mechanism of an oligomeric channel protein. Biochemistry 1985, 24, 1915-1920.

63. Arbuthnott, J.P.; Freer, J.H.; Bernheimer, A.W. Physical states of staphylococcal alpha-toxin. J. Bacteriol. 1967, 94, 1170-1177.

64. Remsen, C.C.; Watson, S.W.; Bernheimer, A.W. Evidence for an ordered arrangement in erythrocyte membranes. Biochem. Biophys. Res. Commun. 1970, 40, 1297-1304.

65. Freer, J.H.; Arbuthnott, J.P.; Billcliffe, B. Effects of staphylococcal-toxin on the structure of erythrocyte membranes: A biochemical and freeze-etching study. J. Gen. Microbiol. 1973, 75, 321-332.

66. Arbuthnott, J.P.; Freer, J.H.; Billcliffe, B. Lipid-induced polymerization of staphylococcal-toxin. J. Gen. Microbiol. 1973, 75, 309-319.

67. Arbuthnott, J.P.; Freer, J.H.; McNiven, A.C. Physical properties of staphylococcal alpha-toxin and aspects of alpha-toxin membrane interactions. Contrib. Microbiol. Immunol. 1973, 1, 285-297.

68. Hugo, F.; Sinner, A.; Reichwein, J.; Bhakdi, S. Quantitation of monomeric and oligomeric forms of membrane-bound staphylococcal alpha-toxin by enzyme-linked immunosorbent assay with a neutralizing monoclonal antibody. Infect. Immun. 1987, 55, 2933-2939. 
69. Reichwein, J.; Hugo, F.; Roth, M.; Sinner, A.; Bhakdi, S. Quantitative analysis of the binding and oligomerization of staphylococcal alpha-toxin in target erythrocyte membranes. Infect. Immun. 1987, 55, 2940-2944.

70. Bhakdi, S.; Fussle, R.; Tranum-Jensen, J. Staphylococcal alpha-toxin: Oligomerization of hydrophilic monomers to form amphiphilic hexamers induced through contact with deoxycholate detergent micelles. Proc. Natl. Acad. Sci. USA 1981, 78, 5475-5479.

71. Recsei, P.; Kreiswirth, B.; O’Reilly, M.; Schlievert, P.; Gruss, A.; Novick, R.P. Regulation of exoprotein gene expression in Staphylococcus aureus by agar. Mol. Gen. Genet. 1986, 202, 58-61.

72. Peng, H.L.; Novick, R.P.; Kreiswirth, B.; Kornblum, J.; Schlievert, P. Cloning, characterization, and sequencing of an accessory gene regulator (agr) in Staphylococcus aureus. J. Bacteriol. 1988, 170, 4365-4372.

73. Novick, R.P.; Ross, H.F.; Projan, S.J.; Kornblum, J.; Kreiswirth, B.; Moghazeh, S. Synthesis of staphylococcal virulence factors is controlled by a regulatory RNA molecule. EMBO J. 1993, 12, 3967-3975.

74. Lina, G.; Jarraud, S.; Ji, G.; Greenland, T.; Pedraza, A.; Etienne, J.; Novick, R.P.; Vandenesch, F. Transmembrane topology and histidine protein kinase activity of agrC, the agr signal receptor in Staphylococcus aureus. Mol. Microbiol. 1998, 28, 655-662.

75. Lyon, G.J.; Wright, J.S.; Muir, T.W.; Novick, R.P. Key determinants of receptor activation in the agr autoinducing peptides of Staphylococcus aureus. Biochemistry 2002, 41, 10095-10104.

76. Koenig, R.L.; Ray, J.L.; Maleki, S.J.; Smeltzer, M.S.; Hurlburt, B.K. Staphylococcus aureus agrA binding to the RNAIII-agr regulatory region. J. Bacteriol. 2004, 186, 7549-7555.

77. McNiven, A.C.; Arbuthnott, J.P. Cell-associated alpha-toxin from Staphylococcus aureus. J. Med. Microbiol. 1972, 5, 123-127.

78. Xiong, Y.Q.; Willard, J.; Yeaman, M.R.; Cheung, A.L.; Bayer, A.S. Regulation of Staphylococcus aureus alpha-toxin gene (hla) expression by agr, sarA, and sae in vitro and in experimental infective endocarditis. J. Infect. Dis. 2006, 194, 1267-1275.

79. Reyes, D.; Andrey, D.O.; Monod, A.; Kelley, W.L.; Zhang, G.; Cheung, A.L. Coordinated regulation by agrA, sarA, and sarR to control agr expression in Staphylococcus aureus. J. Bacteriol. 2011, 193, 6020-6031.

80. Cheung, A.L.; Chien, Y.T.; Bayer, A.S. Hyperproduction of alpha-hemolysin in a sigB mutant is associated with elevated sarA expression in Staphylococcus aureus. Infect. Immun. 1999, 67, 1331-1337.

81. Cheung, A.L.; Eberhardt, K.J.; Chung, E.; Yeaman, M.R.; Sullam, P.M.; Ramos, M.; Bayer, A.S. Diminished virulence of a sar-/agr-mutant of Staphylococcus aureus in the rabbit model of endocarditis. J. Clin. Invest. 1994, 94, 1815-1822.

82. Valeva, A.; Hellmann, N.; Walev, I.; Strand, D.; Plate, M.; Boukhallouk, F.; Brack, A.; Hanada, K.; Decker, H.; Bhakdi, S. Evidence that clustered phosphocholine head groups serve as sites for binding and assembly of an oligomeric protein pore. J. Biol. Chem. 2006, 281, 26014-26021.

83. Menestrina, G. Ionic channels formed by Staphylococcus aureus alpha-toxin: Voltage-dependent inhibition by divalent and trivalent cations. J. Membr. Biol. 1986, 90, 177-190. 
84. Watanabe, M.; Tomita, T.; Yasuda, T. Membrane-damaging action of staphylococcal alpha-toxin on phospholipid-cholesterol liposomes. Biochim. Biophys. Acta 1987, 898, 257-265.

85. Belmonte, G.; Cescatti, L.; Ferrari, B.; Nicolussi, T.; Ropele, M.; Menestrina, G. Pore formation by Staphylococcus aureus alpha-toxin in lipid bilayers. Dependence upon temperature and toxin concentration. Eur. Biophys. J. 1987, 14, 349-358.

86. Ikigai, H.; Nakae, T. Assembly of the alpha-toxin-hexamer of Staphylococcus aureus in the liposome membrane. J. Biol. Chem. 1987, 262, 2156-2160.

87. Ikigai, H.; Nakae, T. Interaction of the alpha-toxin of Staphylococcus aureus with the liposome membrane. J. Biol. Chem. 1987, 262, 2150-2155.

88. Forti, S.; Menestrina, G. Staphylococcal alpha-toxin increases the permeability of lipid vesicles by cholesterol- and ph-dependent assembly of oligomeric channels. Eur. J. Biochem. 1989, 181, 767-773.

89. Schwiering, M.; Brack, A.; Stork, R.; Hellmann, N. Lipid and phase specificity of alpha-toxin from S. aureus. Biochim. Biophys. Acta 2013, 1828, 1962-1972.

90. Galdiero, S.; Gouaux, E. High resolution crystallographic studies of alpha-hemolysin-phospholipid complexes define heptamer-lipid head group interactions: Implication for understanding protein-lipid interactions. Protein Sci. 2004, 13, 1503-1511.

91. Tweten, R.K. Cholesterol-dependent cytolysins, a family of versatile pore-forming toxins. Infect. Immun. 2005, 73, 6199-6209.

92. Thay, B.; Wai, S.N.; Oscarsson, J. Staphylococcus aureus alpha-toxin-dependent induction of host cell death by membrane-derived vesicles. PLoS One 2013, 8, e54661.

93. Lee, E.Y.; Choi, D.Y.; Kim, D.K.; Kim, J.W.; Park, J.O.; Kim, S.; Kim, S.H.; Desiderio, D.M.; Kim, Y.K.; Kim, K.P.; et al. Gram-positive bacteria produce membrane vesicles: Proteomics-based characterization of Staphylococcus aureus-derived membrane vesicles. Proteomics 2009, 9, 5425-5436.

94. Wilke, G.A.; Bubeck Wardenburg, J. Role of a disintegrin and metalloprotease 10 in Staphylococcus aureus alpha-hemolysin-mediated cellular injury. Proc. Natl. Acad. Sci. USA 2010, 107, 13473-13478.

95. Gouaux, E.; Hobaugh, M.; Song, L. Alpha-hemolysin, gamma-hemolysin, and leukocidin from Staphylococcus aureus: Distant in sequence but similar in structure. Protein Sci. 1997, 6, 2631-2635.

96. Valeva, A.; Palmer, M.; Bhakdi, S. Staphylococcal $\alpha$-toxin: Formation of the heptameric pore is partially cooperative and proceeds through multiple intermediate stages?. Biochemistry 1997, 36, 13298-13304.

97. Valeva, A.; Pongs, J.; Bhakdi, S.; Palmer, M. Staphylococcal alpha-toxin: The role of the n-terminus in formation of the heptameric pore-A fluorescence study. Biochim. Biophys. Acta 1997, 1325, 281-286.

98. Kawate, T.; Gouaux, E. Arresting and releasing staphylococcal $\alpha$-hemolysin at intermediate stages of pore formation by engineered disulfide bonds. Protein Sci. 2003, 12, 997-1006.

99. Jursch, R.; Hildebrand, A.; Hobom, G.; Tranum-Jensen, J.; Ward, R.; Kehoe, M.; Bhakdi, S. Histidine residues near the $N$-terminus of staphylococcal alpha-toxin as reporters of regions that are critical for oligomerization and pore formation. Infect. Immun. 1994, 62, 2249-2256. 
100. Menzies, B.E.; Kernodle, D.S. Site-directed mutagenesis of the alpha-toxin gene of Staphylococcus aureus: Role of histidines in toxin activity in vitro and in a murine model. Infect. Immun. 1994, 62, 1843-1847.

101. Walker, B.; Bayley, H. Key residues for membrane binding, oligomerization, and pore forming activity of staphylococcal alpha-hemolysin identified by cysteine scanning mutagenesis and targeted chemical modification. J. Biol. Chem. 1995, 270, 23065-23071.

102. Walker, B.; Bayley, H. Restoration of pore-forming activity in staphylococcal alpha-hemolysin by targeted covalent modification. Protein Eng. 1995, 8, 491-495.

103. Jayasinghe, L.; Miles, G.; Bayley, H. Role of the amino latch of staphylococcal alpha-hemolysin in pore formation: A co-operative interaction between the $\mathrm{N}$-terminus and position 217. J. Biol. Chem. 2006, 281, 2195-2204.

104. Meesters, C.; Brack, A.; Hellmann, N.; Decker, H. Structural characterization of the alpha-hemolysin monomer from Staphylococcus aureus. Proteins 2009, 75, 118-126.

105. Foletti, D.; Strop, P.; Shaughnessy, L.; Hasa-Moreno, A.; Casas, M.G.; Russell, M.; Bee, C.; Wu, S.; Pham, A.; Zeng, Z.; et al. Mechanism of action and in vivo efficacy of a human-derived antibody against Staphylococcus aureus alpha-hemolysin. J. Mol. Biol. 2013, 425, 1641-1654.

106. Bhakdi, S.; Jursch, R.; Broker, M.; Ronneberger, H.; Hungerer, K.D. Functionally inactive S. aureus alpha-toxin containing a single amino acid substitution: Potential usefulness as a vaccine. Behring Inst. Mitteilungen 1994, 95, 80-84.

107. Ragle, B.E.; Bubeck Wardenburg, J. Anti-alpha-hemolysin monoclonal antibodies mediate protection against Staphylococcus aureus pneumonia. Infect. Immun. 2009, 77, 2712-2718.

108. Tkaczyk, C.; Hua, L.; Varkey, R.; Shi, Y.; Dettinger, L.; Woods, R.; Barnes, A.; MacGill, R.S.; Wilson, S.; Chowdhury, P.; et al. Identification of anti-alpha toxin monoclonal antibodies that reduce the severity of Staphylococcus aureus dermonecrosis and exhibit a correlation between affinity and potency. Clin. Vaccine Immunol. 2012, 19, 377-385.

109. Adhikari, R.P.; Ajao, A.O.; Aman, M.J.; Karauzum, H.; Sarwar, J.; Lydecker, A.D.; Johnson, J.K.; Nguyen, C.; Chen, W.H.; Roghmann, M.C. Lower antibody levels to Staphylococcus aureus exotoxins are associated with sepsis in hospitalized adults with invasive S. aureus infections. J. Infect. Dis. 2012, 206, 915-923.

110. Roundtree, P.M.; Beard, M.A. Further observations on infections with phage type 80 staphylococci in australia. Med. J. Aust. 1958, 2, 789-795.

111. Gillespie, W.A.; Alder, V.G. Control of an outbreak of staphylococcal infection in a hospital. Lancet 1957, 272, 632-634.

112. Hassall, J.E.; Rountree, P.M. Staphylococcal septicaemia. Lancet 1959, 1, 213-217.

113. DeLeo, F.R.; Kennedy, A.D.; Chen, L.; Bubeck Wardenburg, J.; Kobayashi, S.D.; Mathema, B.; Braughton, K.R.; Whitney, A.R.; Villaruz, A.E.; Martens, C.A.; et al. Molecular differentiation of historic phage-type 80/81 and contemporary epidemic Staphylococcus aureus. Proc. Natl. Acad. Sci. USA 2011, 108, 18091-18096.

114. Montgomery, C.P.; Boyle-Vavra, S.; Adem, P.V.; Lee, J.C.; Husain, A.N.; Clasen, J.; Daum, R.S. Comparison of virulence in community-associated methicillin-resistant Staphylococcus aureus pulsotypes usa300 and usa400 in a rat model of pneumonia. J. Infect. Dis. 2008, 198, 561-570. 
115. Montgomery, C.P.; Boyle-Vavra, S.; Daum, R.S. Importance of the global regulators agr and saeRS in the pathogenesis of CA-MRSA USA300 infection. PLoS One 2010, 5, e15177.

116. Bubeck Wardenburg, J.; Schneewind, O. Vaccine protection against Staphylococcus aureus pneumonia. J. Exp. Med. 2008, 205, 287-294.

117. Barretti, P.; Montelli, A.C.; Batalha, J.E.; Caramori, J.C.; Cunha Mde, L. The role of virulence factors in the outcome of staphylococcal peritonitis in capd patients. BMC Infect. Dis. 2009, 9, 212.

118. Patel, A.H.; Nowlan, P.; Weavers, E.D.; Foster, T. Virulence of protein a-deficient and alpha-toxin-deficient mutants of Staphylococcus aureus isolated by allele replacement. Infect. Immun. 1987, 55, 3103-3110.

119. Menzies, B.E.; Kernodle, D.S. Passive immunization with antiserum to a nontoxic alpha-toxin mutant from Staphylococcus aureus is protective in a murine model. Infect. Immun. 1996, 64, 1839-1841.

120. O’Reilly, M.; de Azavedo, J.C.; Kennedy, S.; Foster, T.J. Inactivation of the alpha-haemolysin gene of Staphylococcus aureus $8325-4$ by site-directed mutagenesis and studies on the expression of its haemolysins. Microbial. Pathog. 1986, 1, 125-138.

121. Rauch, S.; DeDent, A.C.; Kim, H.K.; Bubeck Wardenburg, J.; Missiakas, D.M.; Schneewind, O. Abscess formation and alpha-hemolysin induced toxicity in a mouse model of Staphylococcus aureus peritoneal infection. Infect. Immun. 2012, 80, 3721-3732.

122. Bayer, A.S.; Ramos, M.D.; Menzies, B.E.; Yeaman, M.R.; Shen, A.J.; Cheung, A.L. Hyperproduction of alpha-toxin by Staphylococcus aureus results in paradoxically reduced virulence in experimental endocarditis: A host defense role for platelet microbicidal proteins. Infect. Immun. 1997, 65, 4652-4660.

123. Bramley, A.J.; Patel, A.H.; O’Reilly, M.; Foster, R.; Foster, T.J. Roles of alpha-toxin and beta-toxin in virulence of Staphylococcus aureus for the mouse mammary gland. Infect. Immun. 1989, 57, 2489-2494.

124. Jonsson, P.; Lindberg, M.; Haraldsson, I.; Wadstrom, T. Virulence of staphylococcus aureus in a mouse mastitis model: Studies of alpha hemolysin, coagulase, and protein a as possible virulence determinants with protoplast fusion and gene cloning. Infect. Immun. 1985, 49, 765-769.

125. McGee, M.P.; Kreger, A.; Leake, E.S.; Harshman, S. Toxicity of staphylococcal alpha toxin for rabbit alveolar macrophages. Infect. Immun. 1983, 39, 439-444.

126. Yarovinsky, T.O.; Monick, M.M.; Husmann, M.; Hunninghake, G.W. Interferons increase cell resistance to staphylococcal alpha-toxin. Infect. Immun. 2008, 76, 571-577.

127. Hruz, P.; Zinkernagel, A.S.; Jenikova, G.; Botwin, G.J.; Hugot, J.P.; Karin, M.; Nizet, V.; Eckmann, L. Nod2 contributes to cutaneous defense against Staphylococcus aureus through alpha-toxin-dependent innate immune activation. Proc. Natl. Acad. Sci. USA 2009, 106, 12873-12878.

128. Lizak, M.; Yarovinsky, T.O. Phospholipid scramblase 1 mediates type I interferon-induced protection against staphylococcal alpha-toxin. Cell Host Microbe 2012, 11, 70-80.

129. Seals, D.F. The adams family of metalloproteases: Multidomain proteins with multiple functions. Genes Dev. 2003, 17, 7-30.

130. Edwards, D.; Handsley, M.; Pennington, C. The adam metalloproteinases. Mol. Aspects Med. 2008, 29, 258-289. 
131. Nagano, O.; Murakami, D.; Hartmann, D.; de Strooper, B.; Saftig, P.; Iwatsubo, T.; Nakajima, M.; Shinohara, M.; Saya, H. Cell-matrix interaction via cd44 is independently regulated by different metalloproteinases activated in response to extracellular $\mathrm{Ca}(2+)$ influx and $\mathrm{PKC}$ activation. J. Cell Biol. 2004, 165, 893-902.

132. Allinson, T.M.; Parkin, E.T.; Turner, A.J.; Hooper, N.M. Adams family members as amyloid precursor protein alpha-secretases. J. Neurosci. Res. 2003, 74, 342-352.

133. Maretzky, T.; Reiss, K.; Ludwig, A.; Buchholz, J.; Scholz, F.; Proksch, E.; de Strooper, B.; Hartmann, D.; Saftig, P. Adam10 mediates E-cadherin shedding and regulates epithelial cell-cell adhesion, migration, and beta-catenin translocation. Proc. Natl. Acad. Sci. USA 2005, 102, 9182-9187.

134. Janes, P.W.; Saha, N.; Barton, W.A.; Kolev, M.V.; Wimmer-Kleikamp, S.H.; Nievergall, E.; Blobel, C.P.; Himanen, J.P.; Lackmann, M.; Nikolov, D.B. Adam meets eph: An adam substrate recognition module acts as a molecular switch for ephrin cleavage in trans. Cell 2005, 123, 291-304.

135. Gardiner, E.E.; Karunakaran, D.; Shen, Y.; Arthur, J.F.; Andrews, R.K.; Berndt, M.C. Controlled shedding of platelet glycoprotein (GP)VI and GPIb-IX-V by adam family metalloproteinases. J. Thromb. Haemost. 2007, 5, 1530-1537.

136. Schulte, A.; Schulz, B.; Andrzejewski, M.; Hundhausen, C.; Mletzko, S.; Achilles, J.; Reiss, K.; Paliga, K.; Weber, C.; Rosejohn, S. Sequential processing of the transmembrane chemokines cx3cl1 and cxcl16 by $\alpha$ - and $\gamma$-secretases. Biochem. Biophys. Res. Commun. 2007, 358, 233-240.

137. Schulz, B.; Pruessmeyer, J.; Maretzky, T.; Ludwig, A.; Blobel, C.P.; Saftig, P.; Reiss, K. Adam10 regulates endothelial permeability and t-cell transmigration by proteolysis of vascular endothelial cadherin. Circ. Res. 2008, 102, 1192-1201.

138. Gibb, D.R.; El Shikh, M.; Kang, D.J.; Rowe, W.J.; El Sayed, R.; Cichy, J.; Yagita, H.; Tew, J.G.; Dempsey, P.J.; Crawford, H.C.; et al. Adam10 is essential for notch2-dependent marginal zone b cell development and CD23 cleavage in vivo. J. Exp. Med. 2010, 207, 623-635.

139. Saftig, P.; Reiss, K. The "a disintegrin and metalloproteases" ADAM10 and ADAM17: Novel drug targets with therapeutic potential? Eur. J. Cell Biol. 2011, 90, 527-535.

140. Horiuchi, K.; Le Gall, S.; Schulte, M.; Yamaguchi, T.; Reiss, K.; Murphy, G.; Toyama, Y.; Hartmann, D.; Saftig, P.; Blobel, C.P. Substrate selectivity of epidermal growth factor-receptor ligand sheddases and their regulation by phorbol esters and calcium influx. Mol. Biol. Cell 2006, $18,176-188$.

141. Hartmann, D.; de Strooper, B.; Serneels, L.; Craessaerts, K.; Herreman, A.; Annaert, W.; Umans, L.; Lubke, T.; Lena Illert, A.; von Figura, K.; et al. The disintegrin/metalloprotease adam 10 is essential for notch signalling but not for alpha-secretase activity in fibroblasts. Hum. Mol. Genet. 2002, 11, 2615-2624.

142. Tian, L.; Wu, X.; Chi, C.; Han, M.; Xu, T.; Zhuang, Y. Adam10 is essential for proteolytic activation of notch during thymocyte development. Int. Immunol. 2008, 20, 1181-1187.

143. Weber, S.; Niessen, M.T.; Prox, J.; Lullmann-Rauch, R.; Schmitz, A.; Schwanbeck, R.; Blobel, C.P.; Jorissen, E.; de Strooper, B.; Niessen, C.M.; et al. The disintegrin/metalloproteinase ADAM10 is essential for epidermal integrity and notch-mediated signaling. Development 2011, $138,495-505$. 
144. Glomski, K.; Monette, S.; Manova, K.; de Strooper, B.; Saftig, P.; Blobel, C.P. Deletion of ADAM10 in endothelial cells leads to defects in organ-specific vascular structures. Blood 2011, 118, 1163-1174.

145. Zhang, C.; Tian, L.; Chi, C.; Wu, X.; Yang, X.; Han, M.; Xu, T.; Zhuang, Y.; Deng, K. ADAM10 is essential for early embryonic cardiovascular development. Dev. Dyn. 2010, 239, 2594-2602.

146. Jorissen, E.; Prox, J.; Bernreuther, C.; Weber, S.; Schwanbeck, R.; Serneels, L.; Snellinx, A.; Craessaerts, K.; Thathiah, A.; Tesseur, I.; et al. The disintegrin/metalloproteinase ADAM10 is essential for the establishment of the brain cortex. J. Neurosci. 2010, 30, 4833-4844.

147. Yoda, M.; Kimura, T.; Tohmonda, T.; Uchikawa, S.; Koba, T.; Takito, J.; Morioka, H.; Matsumoto, M.; Link, D.C.; Chiba, K.; et al. Dual functions of cell-autonomous and non-cell-autonomous ADAM10 activity in granulopoiesis. Blood 2011, 118, 6939-6942.

148. Bhakdi, S.; Muhly, M.; Korom, S.; Hugo, F. Release of interleukin-1 beta associated with potent cytocidal action of staphylococcal alpha-toxin on human monocytes. Infect. Immun. 1989, 57, 3512-3519.

149. Suttorp, N.; Seeger, W.; Dewein, E.; Bhakdi, S.; Roka, L. Staphylococcal alpha-toxin-induced PGI2 production in endothelial cells: Role of calcium. Am. J. Physiol. 1985, 248, C127-C134.

150. Rose, F.; Dahlem, G.; Guthmann, B.; Grimminger, F.; Maus, U.; Hanze, J.; Duemmer, N.; Grandel, U.; Seeger, W.; Ghofrani, H.A. Mediator generation and signaling events in alveolar epithelial cells attacked by S. aureus alpha-toxin. Am. J. Physiol. Lung Cell. Mol. Physiol. 2002, 282, L207-L214.

151. Suttorp, N.; Fuhrmann, M.; Tannert-Otto, S.; Grimminger, F.; Bhadki, S. Pore-forming bacterial toxins potently induce release of nitric oxide in porcine endothelial cells. J. Exp. Med. 1993, 178, $337-341$.

152. Seeger, W.; Birkemeyer, R.G.; Ermert, L.; Suttorp, N.; Bhakdi, S.; Duncker, H.R. Staphylococcal alpha-toxin-induced vascular leakage in isolated perfused rabbit lungs. Lab. Investig. J. Tech. Methods Pathol. 1990, 63, 341-349.

153. Buerke, M.; Sibelius, U.; Grandel, U.; Buerke, U.; Grimminger, F.; Seeger, W.; Meyer, J.; Darius, H. Staphylococcus aureus alpha toxin mediates polymorphonuclear leukocyte-induced vasocontraction and endothelial dysfunction. Shock 2002, 17, 30-35.

154. Suttorp, N.; Hessz, T.; Seeger, W.; Wilke, A.; Koob, R.; Lutz, F.; Drenckhahn, D. Bacterial exotoxins and endothelial permeability for water and albumin in vitro. Am. J. Physiol. 1988, 255, C368-C376.

155. Maretzky, T.; Scholz, F.; Koten, B.; Proksch, E.; Saftig, P.; Reiss, K. ADAM10-mediated e-cadherin release is regulated by proinflammatory cytokines and modulates keratinocyte cohesion in eczematous dermatitis. J. Invest. Dermatol. 2008, 128, 1737-1746.

156. Le Gall, S.M.; Bobe, P.; Reiss, K.; Horiuchi, K.; Niu, X.D.; Lundell, D.; Gibb, D.R.; Conrad, D.; Saftig, P.; Blobel, C.P. ADAMS 10 and 17 represent differentially regulated components of a general shedding machinery for membrane proteins such as transforming growth factor alpha, 1-selectin, and tumor necrosis factor alpha. Mol. Biol. Cell 2009, 20, 1785-1794. 
157. McElroy, M.C.; Harty, H.R.; Hosford, G.E.; Boylan, G.M.; Pittet, J.F.; Foster, T.J. Alpha-toxin damages the air-blood barrier of the lung in a rat model of Staphylococcus aureus-induced pneumonia. Infect. Immun. 1999, 67, 5541-5544.

158. Parker, D.; Prince, A. Immunopathogenesis of Staphylococcus aureus pulmonary infection. Semin. Immunopathol. 2012, 34, 281-297.

159. Miller, L.S.; Cho, J.S. Immunity against Staphylococcus aureus cutaneous infections. Nat. Rev. Immunol. 2011, 11, 505-518.

160. Bartlett, A.H.; Foster, T.J.; Hayashida, A.; Park, P.W. Alpha-toxin facilitates the generation of cxc chemokine gradients and stimulates neutrophil homing in Staphylococcus aureus pneumonia. J. Infect. Dis. 2008, 198, 1529-1535.

161. Suttorp, N.; Buerke, M.; Tannert-Otto, S. Stimulation of paf-synthesis in pulmonary artery endothelial cells by Staphylococcus aureus alpha-toxin. Thromb. Res. 1992, 67, 243-252.

162. Onogawa, T. Staphylococcal alpha-toxin synergistically enhances inflammation caused by bacterial components. FEMS Immunol. Med. Microbiol. 2002, 33, 15-21.

163. Fink, S.L.; Cookson, B.T. Apoptosis, pyroptosis, and necrosis: Mechanistic description of dead and dying eukaryotic cells. Infect. Immun. 2005, 73, 1907-1916.

164. Ragle, B.E.; Karginov, V.A.; Bubeck Wardenburg, J. Prevention and treatment of Staphylococcus aureus pneumonia with a beta-cyclodextrin derivative. Antimicrob. Agents Chemother. 2010, 54, 298-304.

165. Miller, L.S.; Pietras, E.M.; Uricchio, L.H.; Hirano, K.; Rao, S.; Lin, H.; O’Connell, R.M.; Iwakura, Y.; Cheung, A.L.; Cheng, G.; et al. Inflammasome-mediated production of il-1beta is required for neutrophil recruitment against Staphylococcus aureus in vivo. J. Immunol. 2007, 179, 6933-6942.

166. Niebuhr, M.; Mamerow, D.; Heratizadeh, A.; Satzger, I.; Werfel, T. Staphylococcal alpha-toxin induces a higher $\mathrm{t}$ cell proliferation and interleukin-31 in atopic dermatitis. Int. Arch. Allergy Immunol. 2011, 156, 412-415.

167. Cho, J.S.; Pietras, E.M.; Garcia, N.C.; Ramos, R.I.; Farzam, D.M.; Monroe, H.R.; Magorien, J.E.; Blauvelt, A.; Kolls, J.K.; Cheung, A.L.; et al. Il-17 is essential for host defense against cutaneous Staphylococcus aureus infection in mice. J. Clin. Invest. 2010, 120, 1762-1773.

168. Deshmukh, H.S.; Hamburger, J.B.; Ahn, S.H.; McCafferty, D.G.; Yang, S.R.; Fowler, V.G., Jr. Critical role of NOD2 in regulating the immune response to Staphylococcus aureus. Infect. Immun. 2009, 77, 1376-1382.

169. Van Beelen, A.J.; Zelinkova, Z.; Taanman-Kueter, E.W.; Muller, F.J.; Hommes, D.W.; Zaat, S.A.; Kapsenberg, M.L.; de Jong, E.C. Stimulation of the intracellular bacterial sensor NOD2 programs dendritic cells to promote interleukin-17 production in human memory $\mathrm{T}$ cells. Immunity 2007, 27, 660-669.

170. Valeva, A.; Walev, I.; Gerber, A.; Klein, J.; Palmer, M.; Bhakdi, S. Staphylococcal alpha-toxin: Repair of a calcium-impermeable pore in the target cell membrane. Mol. Microbiol. 2000, 36, $467-476$. 
171. Husmann, M.; Dersch, K.; Bobkiewicz, W.; Beckmann, E.; Veerachato, G.; Bhakdi, S. Differential role of p38 mitogen activated protein kinase for cellular recovery from attack by pore-forming S. aureus alpha-toxin or streptolysin o. Biochem. Biophys. Res. Commun. 2006, 344, 1128-1134.

172. Husmann, M.; Beckmann, E.; Boller, K.; Kloft, N.; Tenzer, S.; Bobkiewicz, W.; Neukirch, C.; Bayley, H.; Bhakdi, S. Elimination of a bacterial pore-forming toxin by sequential endocytosis and exocytosis. FEBS Lett. 2009, 583, 337-344.

173. Bhakdi, S.; Mannhardt, U.; Muhly, M.; Hugo, F.; Ronneberger, H.; Hungerer, K.D. Human hyperimmune globulin protects against the cytotoxic action of staphylococcal alpha-toxin in vitro and in vivo. Infect. Immun. 1989, 57, 3214-3220.

174. Blomqvist, L.; Sjogren, A. Production and characterization of monoclonal antibodies against Staphylococcus aureus alpha-toxin. Toxicon 1988, 26, 265-273.

175. Spaulding, A.R.; Lin, Y.C.; Merriman, J.A.; Brosnahan, A.J.; Peterson, M.L.; Schlievert, P.M. Immunity to Staphylococcus aureus secreted proteins protects rabbits from serious illnesses. Vaccine 2012, 30, 5099-5109.

176. Adhikari, R.P.; Karauzum, H.; Sarwar, J.; Abaandou, L.; Mahmoudieh, M.; Boroun, A.R.; Vu, H.; Nguyen, T.; Devi, V.S.; Shulenin, S.; et al. Novel structurally designed vaccine for S. aureus alpha-hemolysin: Protection against bacteremia and pneumonia. PLoS One 2012, 7, e38567.

177. Pozzi, C.; Wilk, K.; Lee, J.C.; Gening, M.; Nifantiev, N.; Pier, G.B. Opsonic and protective properties of antibodies raised to conjugate vaccines targeting six Staphylococcus aureus antigens. PLoS One 2012, 7, e46648.

(C) 2013 by the authors; licensee MDPI, Basel, Switzerland. This article is an open access article distributed under the terms and conditions of the Creative Commons Attribution license (http://creativecommons.org/licenses/by/3.0/). 